\title{
Thioredoxin and thioredoxin reductase influence estrogen receptor $\alpha$-mediated gene expression in human breast cancer cells
}

\author{
Abhi K Rao', Yvonne S Ziegler ${ }^{2}$, lan X McLeod ${ }^{3}$, John R Yates ${ }^{3}$ and Ann M Nardulli ${ }^{2}$ \\ Departments of ${ }^{1}$ Cellular and Developmental Biology and ${ }^{2}$ Molecular and Integrative Physiology, University of Illinois at Urbana-Champaign, 524 Burrill Hall, \\ 407 South Goodwin Avenue, Urbana, Illinois 61801, USA \\ ${ }^{3}$ Department of Cell Biology, The Scripps Institute, LaJolla, California 92037, USA \\ (Correspondence should be addressed to A M Nardulli; Email: anardull@ life.uiuc.edu)
}

\begin{abstract}
Accumulation of reactive oxygen species (ROS) in cells damages resident proteins, lipids, and DNA. In order to overcome the oxidative stress that occurs with ROS accumulation, cells must balance free radical production with an increase in the level of antioxidant enzymes that convert free radicals to less harmful species. We identified two antioxidant enzymes, thioredoxin (Trx) and Trx reductase (TrxR), in a complex associated with the DNA-bound estrogen receptor $\alpha(E R \alpha)$. Western analysis and immunocytochemistry were used to demonstrate that $\operatorname{Trx}$ and $\operatorname{TrxR}$ are expressed in the cytoplasm and in the nuclei of MCF-7 human breast cancer cells. More importantly, endogenously expressed $E R \alpha, \operatorname{Trx}$, and $\operatorname{TrxR}$ interact and $E R \alpha$ and $\operatorname{TrxR}$ associate with the native, estrogen-responsive pS2 and progesterone receptor genes in MCF-7 cells. RNA interference assays demonstrated that Trx and TrxR differentially influence estrogen-responsive gene expression and that together, 17 $\beta$-estradiol, Trx, and TrxR alter hydrogen peroxide $\left(\mathrm{H}_{2} \mathrm{O}_{2}\right)$ levels in MCF-7 cells. Our findings suggest that Trx and TrxR are multifunctional proteins that, in addition to modulating $\mathrm{H}_{2} \mathrm{O}_{2}$ levels and transcription factor activity, aid $\mathrm{ER} \alpha$ in regulating the expression of estrogen-responsive genes in target cells.
\end{abstract}

Journal of Molecular Endocrinology (2009) 43, 251-261

\section{Introduction}

Eukaryotic cells consume oxygen and produce reactive oxygen species (ROS) as by-products of normal cellular metabolism (Powell et al. 2005). ROS include a number of chemically reactive oxygen derivatives including superoxide and hydrogen peroxide $\left(\mathrm{H}_{2} \mathrm{O}_{2}\right)$, which are less reactive, and hydroxyl radical, which is highly reactive. The initial product of oxygen metabolism, superoxide, is dismutated to $\mathrm{H}_{2} \mathrm{O}_{2}$ in cells by superoxide dismutase (SOD). The $\mathrm{H}_{2} \mathrm{O}_{2}$ is then converted to $\mathrm{H}_{2} \mathrm{O}$ and $\mathrm{O}_{2}$ by catalase, glutathione peroxidase, and peroxiredoxins, which include thioredoxin (Trx) peroxidases (Beckman et al. 1990, Webster et al. 2001, Yoshida et al. 2003, Smart et al. 2004, Hashemy et al. 2006).

ROS are needed to serve as molecular messengers in cell-signaling pathways and in the immune system to target pathogens (Lehnert \& Iyer 2002, Feinendegen 2005, Goldstein et al. 2005). At low concentrations, superoxide and $\mathrm{H}_{2} \mathrm{O}_{2}$ are effective stimulators of cell growth (Burdon 1995). However, if $\mathrm{H}_{2} \mathrm{O}_{2}$ is not effectively eliminated, hydroxyl radicals can accumulate and damage proteins, lipids, and DNA (Halliwell \& Gutteridge 1985, Storz et al. 1990). Increased ROS accumulation has also been linked to tumorigenesis and age-related diseases (Kirkwood \& Austad 2000, Toussaint $e$ t al. 2002) as well as decreased cell survival (Salganik 2001). Thus, oxygen radicals have beneficial as well as detrimental effects.

In order to avoid ROS accumulation and its damaging effects, cells express a battery of oxidative stress response proteins that dissipate oxygen radicals (Halliwell \& Gutteridge 1985, Storz et al. 1990). Trx is an oxidative stress response protein that activates i) transcription factors in order to alter gene expression and ii) peroxiredoxins, so that cellular $\mathrm{H}_{2} \mathrm{O}_{2}$ can be diminished (Webster et al. 2001, Arner \& Holmgren 2006). Like the proteins that it reduces, Trx itself must be reduced in order to activate other proteins. Trx reductase (TrxR) utilizes NADPH to reduce and activate Trx as well as other proteins (Mustacich \& Powis 2000). By maintaining protein thiols in the reduced state, Trx and TrxR help to maintain a reduced cellular environment and active transcription factors (Holmgren 1979, 1985, Das et al. 1997).

Zinc finger proteins are particularly susceptible to oxidation. Oxidation of zinc finger proteins diminishes the ability of these proteins to interact with their target DNA sequences and ultimately alters gene expression.

DOI: 10.1677/JME-09-0053 Online version via http://www.endocrinology-journals.org 
Oxidation of two nuclear receptor superfamily members, the glucocorticoid receptor and estrogen receptor $\alpha(E R \alpha)$, diminishes the ability of these proteins to bind to DNA (Makino et al. 1996, Hayashi et al. 1997).

$\mathrm{ER} \alpha$ binds to hormone, dimerizes, interacts directly with its recognition sequences in DNA, estrogenresponse elements (EREs), and recruits coregulatory proteins that influence estrogen-responsive gene expression. Because we had previously shown that three other oxidative stress proteins, SOD1, protein disulfide isomerase (PDI), and apurinic/apyrimidinic endonuclease 1 or redox factor-1 (Ape1/Ref-1) influence ER $\alpha$-mediated gene expression (Schultz-Norton et al. 2006, Rao et al. 2008, Curtis et al. 2009), we were intrigued by the identification of Trx and TrxR in a complex of proteins associated with the DNA-bound $\mathrm{ER} \alpha$ (Schultz-Norton et al. 2008, 2009) and were interested in determining whether Trx and TrxR might also influence $\mathrm{ER} \alpha$-mediated gene expression. We now show that Trx and TrxR alter estrogenresponsive gene expression and that together, $17 \beta$ estradiol $\left(\mathrm{E}_{2}\right)$, Trx, and TrxR modulate $\mathrm{H}_{2} \mathrm{O}_{2}$ levels in MCF-7 human breast cancer cells.

\section{Materials and methods}

\section{Cell culture}

MCF-7 human breast cancer cells, which express ER $\alpha$, were maintained in phenol red-containing minimum essential medium (MEM, Invitrogen) with $1 \times$ nonessential amino acids (NEAA, Invitrogen), $20 \mathrm{mM}$ HEPES, and antibiotics (penicillin-streptomycin and gentamicin) with $5 \%$ calf serum. Cells were switched to phenol red-free MEM with 5\% charcoal/dextrantreated calf serum (CDCS, Eckert \& Katzenellenbogen 1982), NEAA, and antibiotics for 1-3 days before experiments were initiated. MDA-MB-231 human breast cancer cells, which do not express $\mathrm{ER} \alpha$, were maintained in Leibovitz's L-15 medium (Invitrogen) with the same additives as used for MCF-7 cells. U2 osteosarcoma (U2OS) cells were maintained in MEM with $15 \%$ heatinactivated FCS and with the same additives as used for MCF-7 cells. HeLa cervical cancer cells were maintained in DMEM /Nutrient Mixture F-12 Ham with 5\% heatinactivated FCS and penicillin-streptomycin.

\section{Isolation and identification of Trx and TrxR}

Trx and TrxR were isolated as proteins associated with the ERE-bound ER $\alpha$ using agarose gel shift assays and identified using mass spectrometry analysis as previously described (Schultz-Norton et al. 2008, 2009). Three peptides that contained amino acid sequences unique to Trx 1 (TAFQEALDAAGDKLVVVDFSATWCGPCK, PFFHSLSEK, and EKLEATINELV) and 11 peptides that contained amino acid sequence identical to TrxR1 (VMVLDFVTPTPLGTRWGLGGTCVNVGCIPKKLMHQAALLGQALQDSR, MIEAVQNHIG SLNWGYR, KVVYENAYGQFIGPHR, FLIATGERPR, IGEHMEEHGIK, QFVPIKVEQIEAGTPGR, VVAQSTNSEEIIEGEYNTVMLAIGR, IPVTDEEQTNVPYIYAIGDILEDKVELTPVAIQAGR, FGEENIEVYHSYFWPLEWTIPSR, VVGFHVLGPNAGEVTQGFAAALK, and QLDSTIGIHPVCAEVFTTLSVTK) were identified. Together, these peptides account for $45 \cdot 7$ and $49 \cdot 7 \%$ of the total Trx and TrxR amino acid sequences respectively.

\section{Western-blot experiments}

Nuclear extracts from human breast (MCF-7 and MDAMB-231), bone (U2OS), and cervical (HeLa) cancer cells were prepared as described (Wood et al. 2001). Ten micrograms of nuclear extract were fractionated on 10-18\% SDS-polyacrylamide gels, and transferred to a nitrocellulose membrane, which was probed with a Trx-, TrxR-, ER $\alpha$ - (sc-20146, sc-28321, sc-8002 respectively, Santa Cruz Biotechnologies, Santa Cruz, CA, USA), PR-A- and PR-B- (RM-9102-S1, Lab Vision, Fremont, CA, USA), or GAPDH- (TAB1001, Open Biosystems, Huntsville, AL, USA) specific antibody and a HRP-conjugated secondary antibody. Proteins were detected by the SuperSignal West Femto Maximum Sensitivity Substrate chemiluminescent system (Pierce, Rockford, IL, USA).

\section{Immunocytochemistry}

MCF-7 cells were plated onto coverslips in six-well plates containing phenol red-free MEM with NEAA, antibiotics, and 5\% CDCS. Three wells were treated with ethanol vehicle or with $10 \mathrm{nM} \mathrm{E}$. After $24 \mathrm{~h}$, cells were washed with PBS, fixed in PBS with $4 \%$ formaldehyde for $10 \mathrm{~min}$, washed with PBS, permeabilized with PBS containing $0 \cdot 1 \%$ Triton X-100 for $20 \mathrm{~min}$, and washed with PBS containing $0 \cdot 1 \%$ Tween 20 (PBST). Samples were blocked with PBST containing 2\% BSA and 2\% fetal bovine serum for $30 \mathrm{~min}$, incubated with a Trx- or TrxR-specific antibody (sc-20146 and sc-28321 respectively, Santa Cruz Biotechnologies) for $1 \mathrm{~h}$ in a humidified chamber, washed with PBST, incubated with donkey anti-rabbit biotin-SP-conjugated antibody (Trx, 711-066-152) or donkey anti-mouse biotin-SP-conjugated antibody (TrxR, 715-066-150, Jackson ImmunoResearch, West Grove, PA, USA) for $30 \mathrm{~min}$, washed with PBST, incubated with DyLight 549-conjugated Streptavidin (016-500-084, Jackson ImmunoResearch) for $30 \mathrm{~min}$ in the dark, and washed with PBST. Primary antibodies were omitted in control slides and 
run in parallel to demonstrate the specificity of the Trx and TrxR antibodies. Samples were mounted with Vectashield (Vector Laboratories Inc., Burlingame, CA, USA) and visualized with a 40X objective using a Leica DM4000 B confocal microscope (Leica Microsystems, Inc., Bannockburn, IL, USA) with the Leica TCS SPE system and Application Suite Advanced Fluorescence software. Three fields were examined in three independent experiments so that nine fields were examined for each treatment.

\section{Immunoprecipitation assays}

MCF-7 cells were treated with ethanol or $10 \mathrm{nM} \mathrm{E} \mathrm{E}_{2}$ for $0 \cdot 75 \mathrm{~h}$, washed with PBS, harvested in $20 \mathrm{mM}$ Tris $\mathrm{pH}$ $7 \cdot 4,10 \mathrm{mM}$ EDTA, $100 \mathrm{mM} \mathrm{NaCl}, 0 \cdot 5 \%$ NP-40, $1 \mathrm{mM}$ $\mathrm{Na}_{3} \mathrm{VO}_{4}, 50 \mathrm{mM} \mathrm{NaF}$, and $1 \times$ protease inhibitor cocktail (PIC, Sigma), and then pelleted at $20800 \mathrm{~g}$ at $4^{\circ} \mathrm{C}$ for $10 \mathrm{~min}$. The protein concentration of each supernatant was determined using the Bio-Rad protein assay (Bio-Rad) with BSA as a standard. One microgram of Trx- or TrxR-specific antibody (sc-18215 or sc-31057 respectively, Santa Cruz Biotechnologies) or a control antibody directed against fluorescein (Immunological Resource Center, University of Illinois, Urbana, IL, USA) was incubated with $500 \mu \mathrm{g}$ of extract overnight at $4{ }^{\circ} \mathrm{C}$ with rotation, incubated with $60 \mu \mathrm{l}$ of a $50 \%$ Protein G Sepharose slurry for $1 \mathrm{~h}$ (GE Healthcare, Piscataway, NJ, USA), and centrifuged at $960 \mathrm{~g}$ at $4^{\circ} \mathrm{C}$ for $2 \mathrm{~min}$. Samples were washed thrice with $20 \mathrm{mM}$ Tris pH 7.4, $10 \mathrm{mM}$ EDTA, $100 \mathrm{mM} \mathrm{NaCl}, 0 \cdot 1 \% \mathrm{NP}-40$, $1 \mathrm{mM} \mathrm{Na} \mathrm{VO}_{4}, 50 \mathrm{mM} \mathrm{NaF}$, and $1 \times$ PIC before fractionation on SDS-polyacrylamide gels and western analysis with an ER $\alpha$-specific antibody (sc-543, Santa Cruz Biotechnologies).

\section{Chromatin immunoprecipitation assays}

MCF-7 cells were treated with ethanol or $10 \mathrm{nM} \mathrm{E_{2 }}$ for 0.75 or $24 \mathrm{~h}$ and incubated with $1 \%$ formaldehyde. Cells were processed essentially as described (Curtis et al. 2007). Antibodies directed against ER $\alpha$ or TrxR (sc-8002 and sc-31057 respectively, Santa Cruz Biotechnologies) were used for chromatin immunoprecipitation (ChIP). Primers specific to the ERE-containing region of the pS2 gene or two regions of the progesterone receptor (PR) gene (JL Boney-Montoya, YS Ziegler, CD Curtis, JA Montoya \& AM Nardulli, unpublished observations), located $205 \mathrm{~kb}$ (PR205) or $221 \mathrm{~kb}$ (PR221) upstream of the PR-B transcription start site, were used for real-time PCR with iQ SYBR Green Supermix (Bio-Rad) and the iCycler PCR thermocycler. Standard curves were generated using 1000, 5000, 10000,50000 , and 100000 copies of each gene for each primer set in each experiment and run in parallel.

\section{RNA interference experiments}

MCF-7 cells were transferred to phenol red-free MEM with NEAA and antibiotics with 5\% CDCS 1 day prior to plating. Cells were seeded in 12-well plates $24 \mathrm{~h}$ before transfection with siLentFect (Bio-Rad) and transferrin (Sigma). We combined 50 pmol small interfering RNA (siRNA) directed against Trx (117158 or 111300), TrxR (111302 or 41855), or control Renilla luciferase (4630, Ambion, Austin, TX, USA) with $500 \mu \mathrm{l}$ phenol red-free medium and incubated this with the cells for $24 \mathrm{~h}$. Cells were then incubated in phenol red-free medium containing ethanol or $10 \mathrm{nM} \mathrm{E}_{2}$ for $24 \mathrm{~h}$. For protein analysis, cells were harvested with TNE (10 mM Tris, $\mathrm{pH} 7 \cdot 5,150 \mathrm{mM} \mathrm{NaCl}$, and $1 \mathrm{mM}$ EDTA), lysed in lysis buffer $(20 \mathrm{mM}$ Tris pH $8,1 \mathrm{mM}$ EDTA, $200 \mathrm{mM} \mathrm{NaCl}$, and $0.2 \% \mathrm{NP}-40)$, and subjected to western blot analysis with a Trx-, TrxR- (sc-20146 and sc-28321, Santa Cruz Biotechnologies), PR-A- and PR-B- (RM9102-S1, Lab Vision), or GAPDH- (TAB1001, Open Biosystems) specific antibody. For RNA analysis, cells were resuspended in TRIzol (Invitrogen) and processed according to the manufacturer's instructions. cDNA was prepared using the Reverse Transcription System (Promega), and real-time PCR was performed using iQ SYBR Green Supermix and the iCycler PCR thermocycler (Bio-Rad) with primers specific to Trx (5'-CTTTCTTTCATTCCCTCT TG- $3^{\prime}$ and $5^{\prime}$-GCATTTGACTTCACA CTCTG-3' ${ }^{\prime}$ ), TrxR (5'-TGGAATTGGTGCTTGTG-3' and 5-'TATCTCTTGAC-GGAATCG$3^{\prime}$ ), pS2, PR, cyclin G2, cyclin D1, Bcl2, and 36B4 (Curtis et al. 2007, Creekmore et al. 2008). Standard curves were derived using cDNA equivalents of $0 \cdot 02$, $0 \cdot 2,2$, and $20 \mathrm{ng}$ of RNA and were run in duplicate with each primer set in each experiment.

\section{$\mathrm{H}_{2} \mathrm{O}_{2}$ quantitation}

MCF-7 cells were treated with control, Trx or TrxR siRNA, and ethanol or $\mathrm{E}_{2}$ as described for siRNA experiments. Cells were harvested and centrifuged at $960 \mathrm{~g}$ for $5 \mathrm{~min}$ at $4{ }^{\circ} \mathrm{C}$. The pelleted cells were resuspended in lysis buffer and spun at $20800 \mathrm{~g}$ for $5 \mathrm{~min}$ at $4{ }^{\circ} \mathrm{C}$. The supernatants were transferred to a 96-well plate and Amplex Red (Invitrogen), which interacts with $\mathrm{H}_{2} \mathrm{O}_{2}$ to produce the red fluorescent oxidation product resorufin, was used to determine the level of endogenous $\mathrm{H}_{2} \mathrm{O}_{2}$ (Invitrogen). To derive a standard curve, duplicate samples, which included $250,500,750$, and $1000 \mathrm{nM}$ of $\mathrm{H}_{2} \mathrm{O}_{2}$, were run in parallel. All samples were analyzed with a fluorescence plate reader using $544 \mathrm{~nm}$ for excitation and $590 \mathrm{~nm}$ for fluorescence detection. Protein concentrations were determined using the Bio-Rad protein assay 
(Bio-Rad) and used to normalize each sample for any changes in protein levels that might occur in response to $\mathrm{E}_{2}$.

\section{Statistical analysis}

SAS $9 \cdot 1$ Basic Statistics (SAS Institute, Cary, NC, USA) was used for statistical analysis. One-way ANOVA was used to determine whether there were differences between control and experimental groups. A $P$-value $\leq 0.05$ was considered to be statistically significant.

\section{Results}

\section{Trx and TrxR are present in cytoplasmic and nuclear compartments}

We originally identified Trx and TrxR as proteins associated with the ERE-bound ER $\alpha$ (Schultz-Norton et al. 2008, 2009). Although HeLa nuclear extracts had been utilized in these initial experiments, we examined the expression of these two proteins in various cultured cell lines that have been used to study estrogen responsiveness (Druege et al. 1986, Green et al. 1986, Greene et al. 1986, Katzenellenbogen et al. 1987). Western blot analysis with Trx- and TrxR-specific antibodies demonstrated that both proteins are expressed in ER $\alpha$-positive (MCF-7) and ER $\alpha$-negative (MDA-MB-231) human breast cancer cells, U2OS, and, as expected, HeLa cervical cancer cells (Fig. 1A). Interestingly, when MCF-7 cells were treated with $10 \mathrm{nM} \mathrm{E}_{2}$ for $24 \mathrm{~h}$, the expression of Trx, but not TrxR, was enhanced (Fig. 1B). A GAPDH-specific antibody was used to demonstrate that similar amounts of protein were loaded in each lane.

$\mathrm{ER} \alpha$ resides in the nuclei of MCF-7 cells (SchultzNorton et al. 2006). Although Trx and TrxR have been localized in the nuclei of cultured cells, they have more often been described as cytoplasmic proteins (Arner \& Holmgren 2000, Nordberg \& Arner 2001, Yoshida et al. 2003). To determine whether $\operatorname{Trx}$ and $\operatorname{TrxR}$ were present in the nuclear compartment of MCF-7 cells where they might be able to interact with $\mathrm{ER} \alpha$ and influence gene expression, immunocytochemistry was performed. As seen in Fig. 1C, Trx and TrxR were expressed in the cytoplasm, but were also present in the nuclei of MCF-7 cells. Exposure of MCF-7 cells to $\mathrm{E}_{2}$ for $24 \mathrm{~h}$ dramatically increased Trx expression. The increase in Trx expression might be expected since it has been reported that ER $\alpha$ is associated with the $\operatorname{Trx}$ gene in MCF-7 cells (Carroll et al. 2005). No changes were observed in TrxR expression or the localization of Trx and TrxR with hormone treatment. Thus, although previous studies have reported the ability of ionizing radiation, nitric oxide, or oxidative stress to induce translocation of Trx to the nucleus (Hirota et al. 1999,
A
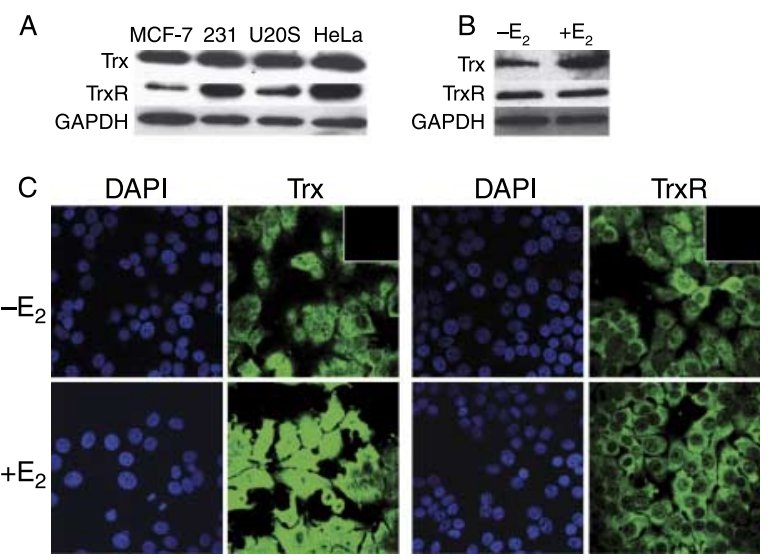

Figure 1 Trx and TrxR expression and localization. (A) The levels of Trx and TrxR were examined in nuclear extracts $(10 \mu \mathrm{g})$ from human $\mathrm{ER} \alpha$-positive breast (MCF-7) and $\mathrm{ER} \alpha$-negative breast (MDA-MB-231), U2 osteosarcoma (U2OS), and cervical (HeLa) cancer cells. (B) Trx and TrxR expression was examined in MCF-7 cells that had been treated with ethanol $\left(-E_{2}\right)$ or $10 \mathrm{nM} \mathrm{E}_{2}$ $\left(+E_{2}\right)$ for $24 \mathrm{~h}$. Samples were fractionated by SDS-PAGE and subjected to western analysis with a Trx- or TrxR-specific antibody. GAPDH levels were monitored to demonstrate that similar amounts of sample were loaded in each lane. (C) MCF-7 cells were treated with ethanol $\left(-E_{2}\right)$ or $10 \mathrm{nM} \mathrm{E}_{2}\left(+\mathrm{E}_{2}\right)$ for $24 \mathrm{~h}$. Expression of Trx and TrxR was monitored using immunocytochemistry with Trx- and TrxR-specific antibodies. DAPI counterstaining was used to detect cell nuclei. The insert in the upper right hand corner of the $-E_{2}$ images demonstrated that when the primary antibody was omitted, the secondary antibodies produced no signal. Full colour version of this figure available via http://dx.doi.org/10.1677/JME-09-0053.

Wei et al. 2000, Arai et al. 2006), $\mathrm{E}_{2}$ did not alter the localization of Trx or TrxR in MCF-7 cells. These findings are consistent with those reported in the Human Protein Atlas (www.proteinatlas.org).

\section{Endogenously expressed Trx, TrxR, and ER $\alpha$ interact}

Because Trx and TrxR were originally isolated in a large complex associated with the DNA-bound ER $\alpha$ using HeLa nuclear extracts (Schultz-Norton et al. 2008, 2009), we determined whether endogenously expressed Trx, TrxR, and ER $\alpha$ from MCF-7 cells could interact. Trx- and TrxR-specific antibodies were used to immunoprecipitate the proteins from MCF-7 extracts, and then western analysis was performed with an ER $\alpha$ specific antibody. ER $\alpha$ was immunoprecipitated with Trx- (Fig. 2A, lanes 5 and 6) and TrxR- (Fig. 2B, lanes 5 and 6) specific antibodies. In contrast, a control antibody directed against fluorescein was unable to immunoprecipitate ER $\alpha$ regardless of whether cells had or had not been exposed to $\mathrm{E}_{2}$ (lanes 3 and 4). These studies demonstrate that endogenously expressed Trx and $\operatorname{TrxR}$ associate with ER $\alpha$ in the absence and in the presence of hormone. 


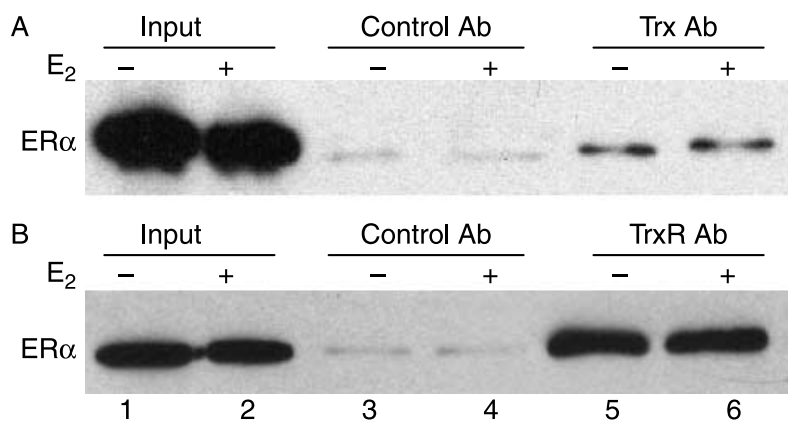

Figure 2 Endogenously expressed Trx, TrxR, and ER $\alpha$ interact. MCF-7 cells were treated with ethanol $\left(-E_{2}\right)$ or $10 n M E_{2}\left(+E_{2}\right)$ for $0.75 \mathrm{~h}$ and lysed. Cell extracts were incubated with $(\mathrm{A})$ Trx- or (B) TrxR- specific antibody. Specifically bound proteins were eluted and subjected to western analysis with an ER $\alpha$-specific antibody. MCF-7 extracts (10\% input) were included in each experiment for comparison. Data shown are representative of three $(A)$ or six $(B)$ independent experiments.

\section{TrxR associates with endogenous estrogen- responsive genes}

The interaction of endogenously expressed ER $\alpha$, Trx, and TrxR (Fig. 2) and the association of Trx and TrxR with the DNA-bound ER $\alpha$ in vitro (Schultz-Norton et al. 2008,2009 ) led us to investigate whether these proteins associate with native estrogen-responsive genes in MCF-7 cells. Using ChIP assays, we previously demonstrated that $\mathrm{ER} \alpha$ and other coregulatory proteins associate with an ERE-containing region of the pS2 gene and with two regions of the PR gene located $205 \mathrm{~kb}$ (PR205) and $221 \mathrm{~kb}$ (PR221) upstream of the PR-B transcription start site (JL Boney-Montoya, YS Ziegler, CD Curtis, JA Montoya \& AM Nardulli, unpublished observations, Schultz-Norton et al. 2006, 2007, Curtis et al. 2007, Creekmore et al. 2008, Rao et al. 2008). PR205 and PR221 contain one and two imperfect EREs respectively.

Significantly more ER $\alpha$ (Fig. 3A) and TrxR (Fig. 3B) were associated with the ERE-containing regions of the pS2 and PR genes in the presence than in the absence of $E_{2}$, suggesting that TrxR may influence estrogen responsiveness of these genes by associating with the DNA-bound $\mathrm{ER} \alpha$ in native chromatin. However, we were unable to detect any significant change in the association of Trx with the pS2 and PR genes in the absence and in the presence of $\mathrm{E}_{2}$ using three different Trx-specific antibodies (data not shown). This could result from the inability of the Trx-specific antibodies to effectively immunoprecipitate Trx (as suggested in Fig. 2A), a transient association of Trx with these gene regions, and/or the relatively small size of $\operatorname{Trx}(12 \mathrm{kDa})$, which could make it less accessible to antibody and more susceptible to epitope masking. No changes were observed in the association of ER $\alpha$ or TrxR with the internal control gene, 36B4, which was used for normalization of each sample.

\section{Trx and TrxR influence endogenous estrogen- responsive gene expression}

To determine more directly whether Trx and TrxR influence the expression of endogenous, estrogenresponsive genes, RNA interference assays were performed to individually knock down Trx and TrxR expression. MCF-7 cells were transfected with siRNA directed against endogenously expressed Trx or TrxR mRNA. In addition, a control siRNA directed against Renilla luciferase, which is not expressed in these cells, was utilized. Trx and TrxR siRNA successfully reduced the protein and mRNA levels of Trx (Fig. 4) and TrxR (Fig. 5) respectively. When control siRNA was used, pS2, PR, cyclin D1, and Bcl2 mRNA and PR protein levels were increased and cyclin G2 mRNA levels were decreased in the presence of $\mathrm{E}_{2}$ (Figs 4 and 5). These findings are consistent with earlier studies from our laboratory and others (Westley \& May 1987, Nardulli et al. 1988, Altucci et al. 1996, Kim et al. 2000, Stossi et al. 2006, Curtis et al. 2007, Creekmore et al. 2008, Rao et al. 2008).
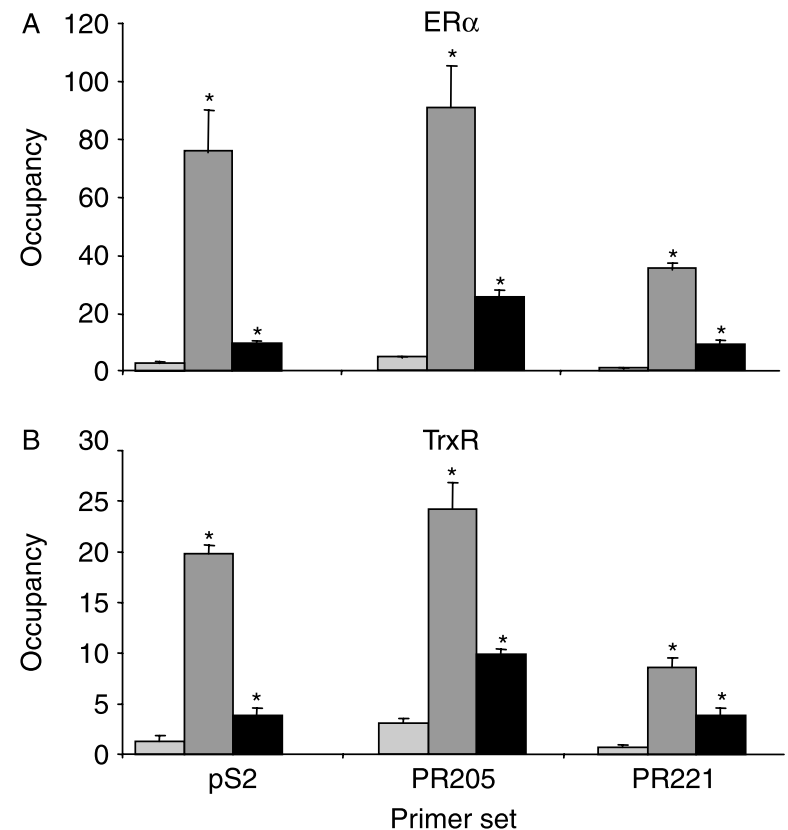

Figure $3 E_{2}$ increases association of TrxR with endogenous, estrogen-responsive genes. MCF-7 cells were treated with ethanol (light gray bars) or $10 \mathrm{nM} \mathrm{E}_{2}$ for 0.75 (dark gray bars) or $24 \mathrm{~h}$ (black bars) and subjected to ChIP analysis with an (A) ER $\alpha$ or (B) TrxR-specific antibody. Quantitative real-time PCR was used to examine the association of $E R \alpha$ and TrxR with the ERE-containing regions of the pS2 and PR (PR205 and PR221) genes. Data are presented as the number of copies of each estrogen-responsive gene region pulled down relative to the number of copies of 36B4 gene region pulled down (occupancy). A significant increase in the association of $\operatorname{ER} \alpha$ and TrxR with these gene regions in the presence of $E_{2}$ is indicated by an asterisk ( $\left.{ }^{\star} P \leq 0.05\right)$. 

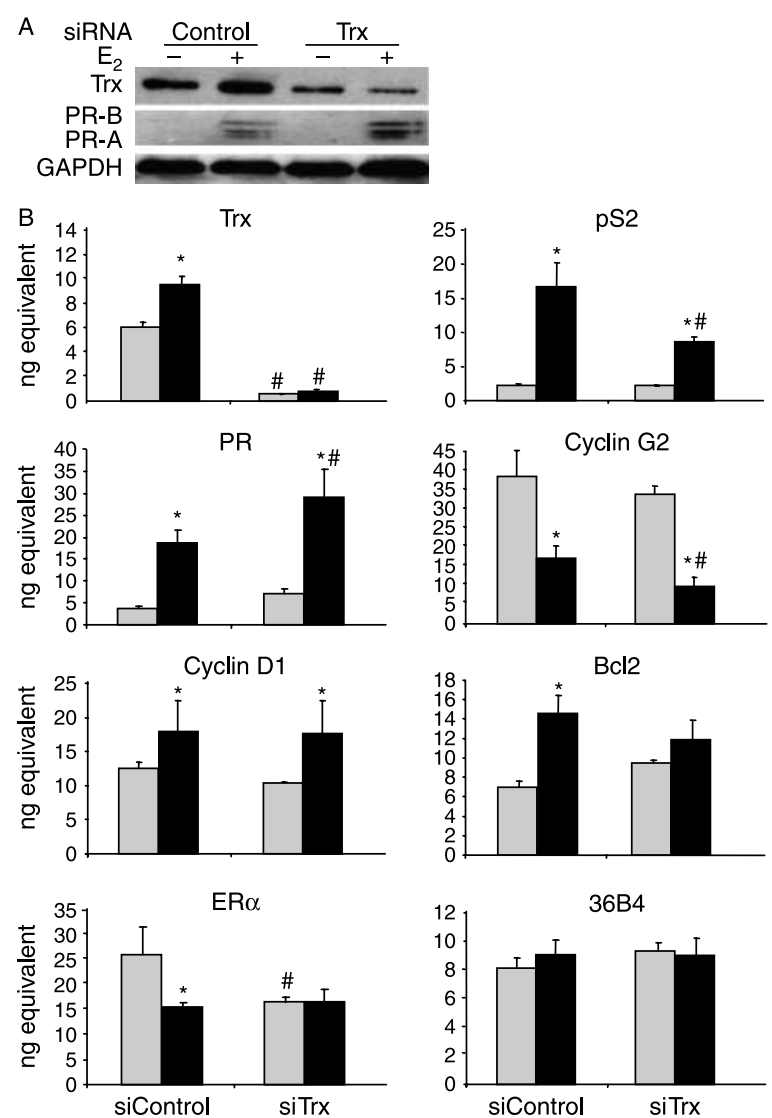

Figure 4 Knocking down Trx influences estrogen responsiveness. MCF-7 cells were transfected with 50 pmol control or Trx siRNA, treated with ethanol ( $-E_{2}$ and light gray bars) or $10 \mathrm{nM} \mathrm{E}_{2}$ ( $+\mathrm{E}_{2}$ and black bars) for $24 \mathrm{~h}$, and processed for protein or mRNA analysis. (A) Proteins were subjected to western analysis with an antibody that recognizes Trx, PR-A and PR-B, or GAPDH.

(B) RNA was isolated and CDNA was synthesized for quantitative RT-PCR analysis with primers specific to Trx, pS2, PR, cyclin G2, cyclin D1, Bcl2, ER $\alpha$, and 36B4 (internal control) mRNA sequences. Data from three independent experiments, which had been performed in triplicate, were combined and are presented as the mean \pm S.E.M. ANOVA was used to detect significant differences in mRNA levels in response to $E_{2}\left({ }^{*} P \leq 0.05\right)$ or in response to Trx siRNA ( $\left.{ }^{\#} P \leq 0.05\right)$.

While the $\mathrm{E}_{2}$-induced increase in $\mathrm{pS} 2 \mathrm{mRNA}$ expression was reduced when Trx siRNA was included, PR mRNA and protein levels were further enhanced (Fig. 4). The $\mathrm{E}_{2}$-induced repression in cyclin G2 was enhanced, resulting in further reduction in cyclin G2 mRNA expression. In contrast, cyclin D1, Bcl2, and ER $\alpha$ mRNA levels were unaltered when Trx expression was reduced. The internal control gene, 36B4, which contains no apparent $\mathrm{ER} \alpha$-binding sites, was unaffected by $\mathrm{E}_{2}$ or the Trx siRNA (Fig. $4 \mathrm{~B}$ ).

When TrxR was knocked down, pS2 and cyclin D1 mRNA levels decreased and PR and Bcl2 mRNA levels as well as PR protein increased in the presence of hormone (Fig. 5). Cyclin G2 mRNA levels were not significantly altered when TrxR expression was reduced and $\mathrm{ER} \alpha$ mRNA levels were decreased in the absence, but not in the presence of $\mathrm{E}_{2}$. Again, $36 \mathrm{~B} 4 \mathrm{mRNA}$ levels were unaffected by $\mathrm{E}_{2}$ or TrxR siRNA (Fig. 5B). The Trx and TrxR siRNAs were protein specific. Decreasing the level of one protein did not significantly affect the expression of the other (data not shown). Furthermore, two different Trx and TrxR siRNAs produced similar effects on estrogenresponsive gene expression. Taken together, these studies indicate that Trx and TrxR have gene-specific, rather than global effects, on estrogen-responsive gene expression.
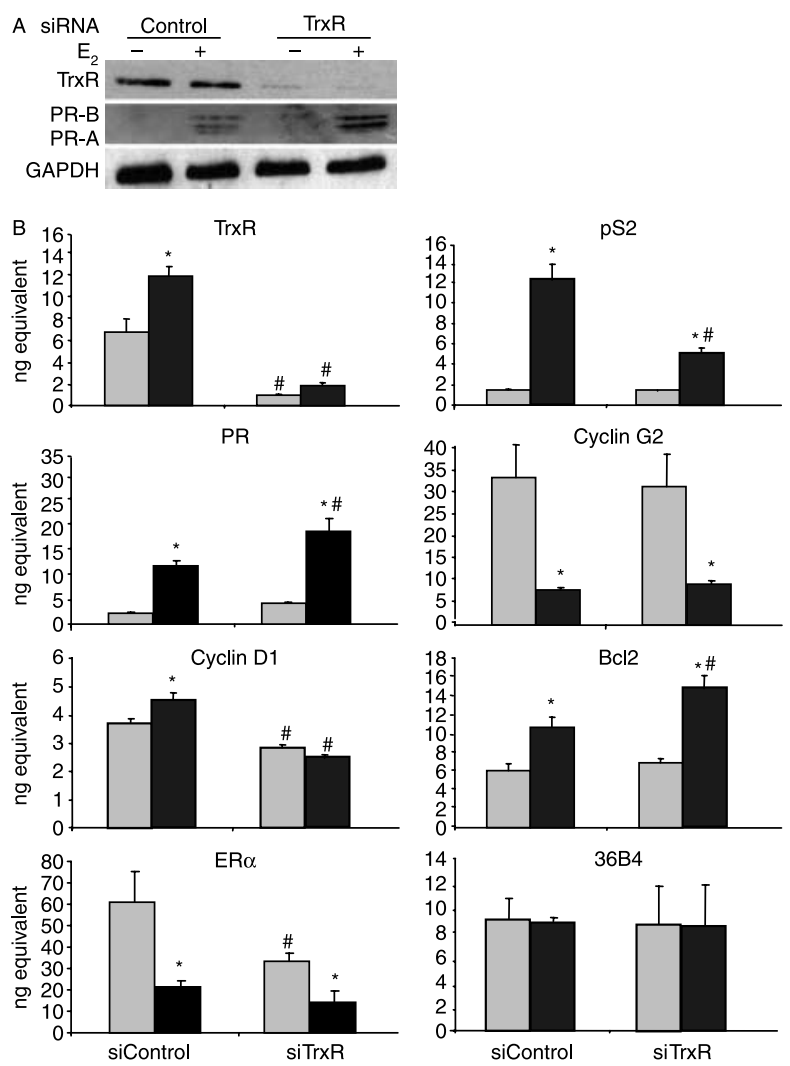

Figure 5 Knocking down TrxR influences estrogen responsiveness. MCF-7 cells were transfected with $50 \mathrm{pmol}$ control or TrxR siRNA, treated with ethanol ( $-E_{2}$ and light gray bars) or $10 \mathrm{nM} \mathrm{E}_{2}$ ( $+E_{2}$ and black bars) for $24 \mathrm{~h}$, and processed for protein or mRNA analysis. (A) Proteins were subjected to western analysis with an antibody that recognizes TrxR, PR-A and PR-B, or GAPDH.

(B) RNA was isolated and CDNA was synthesized for quantitative RT-PCR analysis with primers specific to TrxR, pS2, PR, cyclin $\mathrm{G} 2$, cyclin D1, Bcl2, ER $\alpha$, and 36B4 (internal control) mRNA sequences. Data from three independent experiments, which had been performed in triplicate, were combined and are presented as the mean \pm s.E.M. ANOVA was used to detect significant differences in mRNA levels in response to $\mathrm{E}_{2}\left({ }^{*} P \leq 0.05\right)$ or in response to TrXR siRNA ( $P \leq 0 \cdot 05)$. 


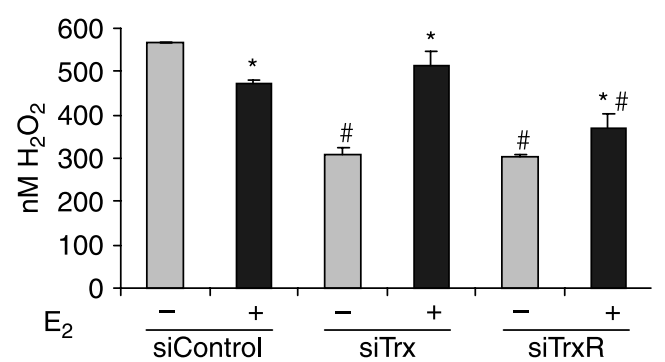

Figure 6 Trx, TrxR, and $\mathrm{E}_{2}$ modulate $\mathrm{H}_{2} \mathrm{O}_{2}$ levels. MCF-7 cells were transfected with $50 \mathrm{pmol}$ control, Trx, or TrxR siRNA and treated with ethanol $\left(-E_{2}\right)$ or $10 n M E_{2}\left(+E_{2}\right)$ for $24 \mathrm{~h}$. Cell extracts were prepared and incubated with Amplex Red to detect the levels of $\mathrm{H}_{2} \mathrm{O}_{2}$. Data from three independent experiments were combined and are expressed as the mean \pm s.E.M. ANOVA was used to detect significant differences in the levels of $\mathrm{H}_{2} \mathrm{O}_{2}$ in the presence of $\mathrm{E}_{2}\left({ }^{\star} P \leq 0.05\right)$ or in response to Trx or TrxR siRNA ( $\left.{ }^{\#} \leq 0.05\right)$.

\section{Trx and TrxR alter $\mathrm{H}_{2} \mathrm{O}_{2}$ levels in MCF-7 cells}

It is well established that Trx influences ROS distribution by activating antioxidant enzymes that convert $\mathrm{H}_{2} \mathrm{O}_{2}$ to $\mathrm{H}_{2} \mathrm{O}$ (Tam et al. 2003, Arner \& Holmgren 2006). Since $\mathrm{E}_{2}$ increases Trx expression (Figs 1 and 4), we hypothesized that $\mathrm{E}_{2}$ treatment might affect $\mathrm{H}_{2} \mathrm{O}_{2}$ levels in MCF-7 cells. Furthermore, since TrxR is required to activate Trx, it seemed possible that TrxR might also play a role in regulating $\mathrm{H}_{2} \mathrm{O}_{2}$ levels. To test these hypotheses, MCF-7 cells that were exposed to control, Trx, or TrxR siRNA in the absence and in the presence of $\mathrm{E}_{2}$ and $\mathrm{H}_{2} \mathrm{O}_{2}$ levels were measured. When control siRNA was used, $\mathrm{H}_{2} \mathrm{O}_{2}$ levels were higher in the absence than in the presence of $\mathrm{E}_{2}$ (Fig. 6). This decreased level in $\mathrm{H}_{2} \mathrm{O}_{2}$ after treatment of MCF-7 cells with $\mathrm{E}_{2}$ for $24 \mathrm{~h}$ most likely results from the dissipation of ROS by the $\mathrm{E}_{2}$-mediated increase in antioxidant proteins (Mobley \& Brueggemeier 2004, Rao et al. 2008).

When Trx or TrxR expression was knocked down and cells were treated with ethanol, $\mathrm{H}_{2} \mathrm{O}_{2}$ levels were significantly reduced. However, when cells were treated with $\mathrm{E}_{2}$ and $\mathrm{Trx}$ or TrxR siRNA, $\mathrm{H}_{2} \mathrm{O}_{2}$ levels were enhanced. These studies demonstrate that individually and collectively Trx, TrxR, and $\mathrm{E}_{2}$ alter $\mathrm{H}_{2} \mathrm{O}_{2}$ levels in MCF-7 cells.

\section{Discussion}

Previous studies have shown that Trx and TrxR help to dissipate ROS, maintain a reduced intracellular environment, and protect cellular macromolecules from oxidative damage (Holmgren 1985, Holmgren \& Bjornstedt 1995, Osborne et al. 2001, Lincoln et al. 2003, Smart et al. 2004). We now demonstrate that endogenously expressed Trx and TrxR interact with $\mathrm{ER} \alpha$ and alter estrogen-responsive gene expression and that together, Trx, TrxR, and $\mathrm{E}_{2}$ influence $\mathrm{H}_{2} \mathrm{O}_{2}$ levels in MCF-7 human breast cancer cells.

\section{Effect of Trx and TrxR on $\mathrm{H}_{2} \mathrm{O}_{2}$ levels}

Although a previous study reported that ROS levels increase when MCF-7 cells are treated with $100 \mu \mathrm{M} \mathrm{E} \mathrm{E}_{2}$ for 15 min (Felty et al. 2005), we, in fact, observed an $\mathrm{E}_{2^{-}}$ dependent reduction in $\mathrm{H}_{2} \mathrm{O}_{2}$ levels when MCF-7 cells had been exposed to $10 \mathrm{nM} \mathrm{E}_{2}$ for $24 \mathrm{~h}$. While the 1000fold difference in $\mathrm{E}_{2}$ concentrations used in these two studies might account for some of the difference observed, we believe that the diminished $\mathrm{H}_{2} \mathrm{O}_{2}$ levels observed after $24 \mathrm{~h}$ of $\mathrm{E}_{2}$ treatment are primarily due to the increased expression of oxidative stress proteins such as SOD1 (Rao et al. 2008) and Trx (Figs 1 and 4), increases that would not be observed after a $15 \mathrm{~min}$ exposure to $\mathrm{E}_{2}$. In addition, although an earlier study monitored $\mathrm{H}_{2} \mathrm{O}_{2}$ levels after the addition of exogenous $\mathrm{H}_{2} \mathrm{O}_{2}$ to the culture media (Mobley \& Brueggemeier 2004), these experiments are distinctly different from our studies in which cells were exposed to vehicle or hormone, and endogenous production of $\mathrm{H}_{2} \mathrm{O}_{2}$ was measured. Overall, our findings support the idea that $\mathrm{E}_{2}$ plays an important role in regulating $\mathrm{H}_{2} \mathrm{O}_{2}$ levels in MCF-7 cells by modulating the expression of oxidative stress proteins.

\section{Effects of Trx and TrxR on estrogen-responsive gene expression}

The capacity of Trx to reduce peroxiredoxins, which convert $\mathrm{H}_{2} \mathrm{O}_{2}$ to $\mathrm{H}_{2} \mathrm{O}$ (Arner \& Holmgren 2006), helps to maintain a reduced intracellular environment and ensure that transcription factors are in a reduced, active state. Thus, Trx along with its activator, TrxR, help in the overall maintenance of transcription factorbinding activity.

The zinc fingers of $E R \alpha$ provide the specificity required for recognizing and interacting with EREcontaining DNA, but are sensitive to oxidative stress (Webster et al. 2001). Although oxidation of ER $\alpha$ by ROS or the oxidizing agent diamide inhibits the ability of the receptor to interact with ERE-containing DNA, its DNA-binding capacity can be restored by the reducing agent dithiothreitol or Trx (Hayashi et al. 1997). The ability of Trx and TrxR to help maintain ER $\alpha$ structure and function is evident in the altered estrogenresponsive gene expression when either protein is knocked down (Figs 4 and 5). Trx also plays an active role in maintaining the DNA-binding activity of other transcription factors including NF- $\mathrm{KB}$, cAMP response element binding protein, p53, Sp1, AP-1 proteins, and the glucocorticoid receptor (Matthews et al. 1992, 
Table 1 Regulation of endogenous, estrogen-responsive genes in MCF-7 cells

$\operatorname{Trx}$

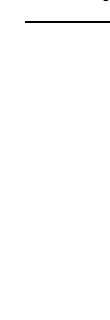

$\operatorname{TrxR}$

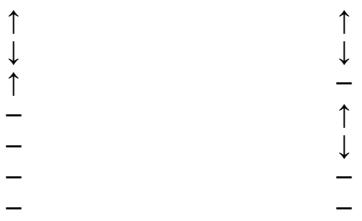

RNA interference experiments demonstrate the gene-specific effects of endogenously expressed Trx and TrxR on estrogen responsiveness.

Wu et al. 1996, Hayashi et al. 1997, Hirota et al. 1997, Liang et al. 1998, Ueno et al. 1999, Webster et al. 2001).

Although we were unable to detect a difference in the association of Trx with the pS2 and PR genes in the absence and in the presence of hormone, the isolation of $\operatorname{Trx}$ in a complex with the DNA-bound ER $\alpha$ (Schultz-Norton et al. 2008, 2009), the immunoprecipitation of $\mathrm{ER} \alpha$ with a Trx-specific antibody in the absence and in the presence of hormone (Fig. 2A), and the ability of Trx to reduce ER $\alpha$ and enhance its binding to DNA (Hayashi et al. 1997) suggest that Trx associates with $\mathrm{ER} \alpha$ at target genes. The $\mathrm{E}_{2}$-induced increase in the association of TrxR with the pS2 and PR genes in the presence of hormone (Fig. 3B) could help to ensure that any Trx associated with these gene regions is active and capable of reducing ER $\alpha$ and its associated coregulatory proteins and influencing transcription. Thus, TrxR, through its modulation of Trx activity, may play a role in reducing proteins and maintaining a reduced environment (Arner \& Holmgren 2000, Nordberg \& Arner 2001). In addition, TrxR has been referred to as a 'redox sensor' (Sun et al. 1999) and may serve in this capacity to help modulate estrogenresponsive gene expression.

Because of their interdependent nature, it was somewhat surprising that Trx and TrxR would have different effects on cyclin G2, cyclin D1, and Bcl2 gene expression (Table 1). However, it is important to remember that estrogen-responsive genes are regulated not simply by ER $\alpha$ alone, but by a complex array of transcription factors and coregulatory proteins bound to multiple cis elements in extended gene regions, and that the association of a single transcription factor with a single gene region cannot necessarily be used to predict the transcriptional response.

\section{Biological roles of Trx and TrxR}

Given the role of Trx and TrxR in influencing estrogenresponsive gene expression, it is not surprising that these two proteins would influence reproductive function. An earlier study suggested that Trx and TrxR were part of a uterine antioxidant system required for maintaining estrogen responsiveness of the uterus (Deroo et al. 2004). These and other studies have shown that $E_{2}$ increases uterine expression of Trx and TrxR in rodents and humans (Maruyama et al. 1997, 1999, Osborne et al. 2001, Deroo et al. 2004). In addition to their roles in reproduction, Trx and TrxR have been implicated in cancer prevention (Urig \& Becker 2006) and progression (Turunen et al. 2004, Biaglow \& Miller 2005, Arner \& Holmgren 2006, Fujino et al. 2006). The ability of Trx and TrxR to alter $\mathrm{H}_{2} \mathrm{O}_{2}$ levels (Fig. 6) could help to maintain gene expression by regulating the redox state of critical transcription factors. Furthermore, they could be essential in avoiding oxidative stress and limiting the damage to cellular macromolecules, which has been associated with aging and age-related disease
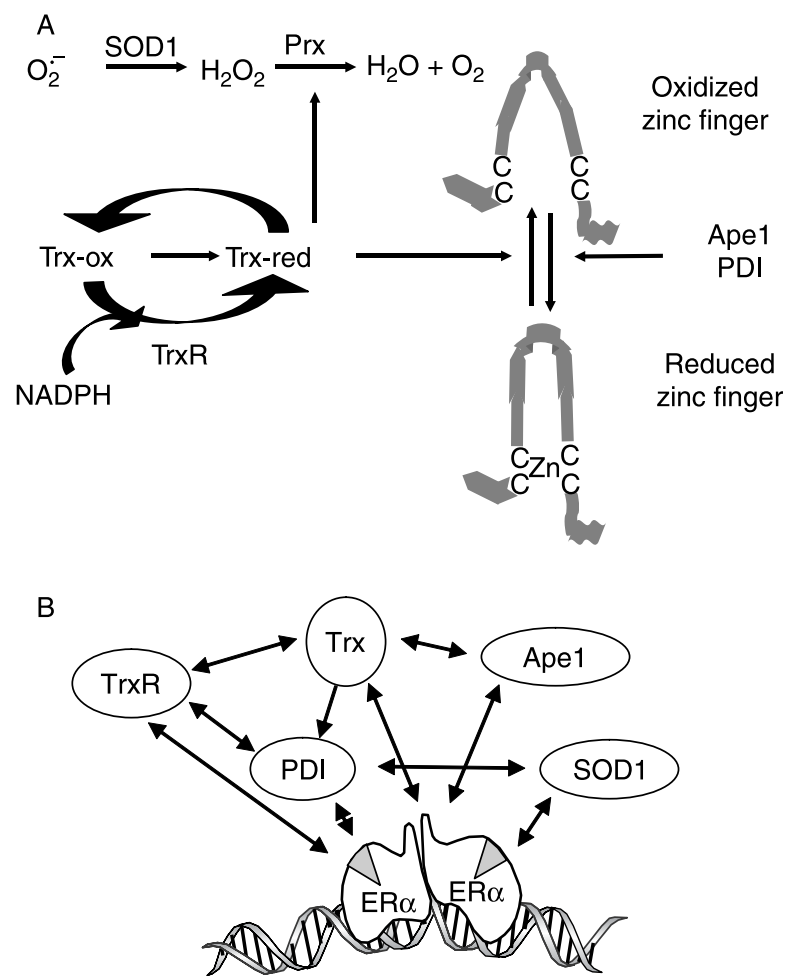

Figure 7 Oxidative stress response protein forms an interconnected network that alters ROS distribution and influences estrogen responsiveness. (A) Oxidized Trx (Trx-ox) is reduced (Trx-red) by TrxR using NADPH as a cofactor. SOD1 dismutates superoxide to form $\mathrm{H}_{2} \mathrm{O}_{2}$ and reduced Trx activates peroxiredoxins (Prx) to help eliminate $\mathrm{H}_{2} \mathrm{O}_{2}$. Trx, Ape1, and PDI reduce zinc finger proteins, enhance interaction with their cognate-binding sites in DNA, and alter transcription. Adapted from Webster et al. 2001. (B) Trx, TrxR, SOD1, PDI, and Ape1 form an interconnected network of proteins (Lundstrom \& Holmgren 1990, Cheung et al. 1999, Wei et al. 2000, Webster et al. 2001, Atkin et al. 2006, Schultz-Norton et al. 2006, 2008, Ando et al. 2008, Rao et al. 2008, Curtis et al. 2009) that are recruited to the DNA-bound ER $\alpha$ (Schultz-Norton et al. 2008) and influence ER $\alpha$-mediated gene expression (Schultz-Norton et al. 2006, Rao et al. 2008, Curtis et al. 2009). 
(Harman 1956, 2001, Finkel \& Holbrook 2000). In fact, the role of $\operatorname{Trx}$ in regulating oxidative stress and influencing the aging process has been previously reported (reviewed in Yoshida et al. (2003)). The overall biological importance of these two proteins is evident in the early embryonic lethality of Trx- and TrxR-null mice (Matsui et al. 1996, Jakupoglu et al. 2005).

\section{Effect of oxidative stress proteins on estrogen responsiveness}

Trx and TrxR cooperate with other enzymes to dissipate intracellular ROS and maintain the capacity of transcription factors to bind to DNA (Fig. 7A, reviewed in Webster et al. (2001)). The conversion of superoxide to $\mathrm{H}_{2} \mathrm{O}_{2}$ by SOD1 is the first line of defense against ROS. TrxR reduces Trx, which in turn activates peroxiredoxins to aid in the conversion of $\mathrm{H}_{2} \mathrm{O}_{2}$ to $\mathrm{H}_{2} \mathrm{O}$ and $\mathrm{O}_{2}$, and enhances binding of transcription factors including $\mathrm{ER} \alpha, \mathrm{AP}-1$ proteins, $\mathrm{NF} \kappa \mathrm{B}$, and p53 to their cognate recognition sequences (Xanthoudakis \& Curran 1992, Hayashi et al. 1997, Jayaraman et al. 1997, Webster et al. 2001, Nishi et al. 2002). PDI catalyzes disulfide bond formation, reduction, and isomerization (Turano et al. 2002), and functions as a molecular chaperone for numerous proteins (Lyles \& Gilbert 1991, Noiva et al. 1993, Wang \& Tsou 1993, Puig et al. 1994, Quan et al. 1995, Schultz-Norton et al. 2006). Ape1 plays a role in DNA repair, redox regulation, and, like Trx, stimulates binding of transcription factors to DNA (Xanthoudakis \& Curran 1992, Jayaraman et al. 1997, Webster et al. 2001, Nishi et al. 2002). Each of these proteins, Trx, TrxR, SOD1, PDI, and Ape1, plays a critical role in regulating oxidative stress, and each influences ER $\alpha$-mediated gene expression in MCF-7 cells (Schultz-Norton et al. 2006, Rao et al. 2008, Curtis et al. 2009). Because of the interdependent nature of these proteins, perturbation in expression of any one protein has the potential to create disequilibrium and alter gene expression and ROS distribution as was observed when Trx or TrxR was knocked down (Figs 4-6).

The current study combined with our previous work (Schultz-Norton et al. 2006, 2008, Rao et al. 2008, Curtis et al. 2009) supports the idea that Trx and TrxR are members of an interconnected network of proteins (Lundstrom \& Holmgren 1990, Cheung et al. 1999, Wei et al. 2000, Webster et al. 2001, Atkin et al. 2006, Schultz-Norton et al. 2006, 2008, Ando et al. 2008, Rao et al. 2008, Curtis et al. 2009), which collectively help to maintain the structural integrity and activity of ER $\alpha$, its associated coregulatory proteins, and other complex members (Fig. 7B). TrxR is required to maintain Trx in an active, reduced state (Webster et al. 2001); Trx reduces Ape1 to bring about changes in transcription factor activity (Wei et al. 2000); Ape1 reduces Trx to influence gene expression (Ando et al. 2008); together,
Trx and TrxR reduce PDI (Lundstrom \& Holmgren 1990); PDI prevents misfolding of many proteins including TrxR and SOD1 (Cheung et al. 1999, Atkin et al. 2006) and acts as a molecular chaperone for ER $\alpha$ (Schultz-Norton et al. 2006); and ER $\alpha$ associates with TrxR, PDI, SOD1, and Ape1 at endogenous estrogenresponsive genes (Fig. 3, Rao et al. 2008, Schultz-Norton et al. 2008, Curtis et al. 2009)). Taken together, our studies suggest that $\mathrm{ER} \alpha$ serves as a nucleating factor to recruit proteins involved in regulating oxidative stress to estrogen-responsive genes, and that oxidative stress proteins are, in turn, instrumental in altering estrogenresponsive gene expression and redox regulation.

\section{Declaration of interest}

None of the authors has a conflict of interest.

\section{Funding}

This work was supported by NIH Grants R01 DK 53884 and R56 DK 53884 (to A M Nardulli) and P41 RR11823-10 (to J R Yates).

\section{Acknowledgements}

We thank Carol Curtis for helpful discussions.

\section{References}

Altucci L, Addeo R, Cicatiello L, Dauvois S, Parker MG, Truss M, Beato M, Sica V, Bresciani F \& Weisz A 1996 17beta-Estradiol induces cyclin D1 gene transcription, p36D1-p34cdk4 complex activation and p105Rb phosphorylation during mitogenic stimulation of $\mathrm{G}(1)$-arrested human breast cancer cells. Oncogene 12 2315-2324.

Ando K, Hirao S, Kabe Y, Ogura Y, Sato I, Yamaguchi Y, Wada T \& Handa H 2008 A new APE1/Ref-1-dependent pathway leading to reduction of NF-kappaB and AP-1, and activation of their DNAbinding activity. Nucleic Acids Research 36 4327-4336.

Arai RJ, Masutani H, Yodoi J, Debbas V, Laurindo FR, Stern A \& Monteiro HP 2006 Nitric oxide induces thioredoxin-1 nuclear translocation: possible association with the p21Ras survival pathway. Biochemical and Biophysical Research Communications 348 1254-1260.

Arner ES \& Holmgren A 2000 Physiological functions of thioredoxin and thioredoxin reductase. European Journal of Biochemistry $\mathbf{2 6 7}$ $6102-6109$.

Arner ES \& Holmgren A 2006 The thioredoxin system in cancer. Seminars in Cancer Biology 16 420-426.

Atkin JD, Farg MA, Turner BJ, Tomas D, Lysaght JA, Nunan J, Rembach A, Nagley P, Beart PM, Cheema SS et al. 2006 Induction of the unfolded protein response in familial amyotrophic lateral sclerosis and association of protein-disulfide isomerase with superoxide dismutase 1. Journal of Biological Chemistry 281 30152-30165.

Beckman JS, Beckman TW, Chen J, Marshall PA \& Freeman BA 1990 Apparent hydroxyl radical production by peroxynitrite: implications for endothelial injury from nitric oxide and superoxide. PNAS 87 1620-1624.

Biaglow JE \& Miller RA 2005 The thioredoxin reductase/thioredoxin system: novel redox targets for cancer therapy. Cancer Biology and Therapy 4 6-13. 
Burdon RH 1995 Superoxide and hydrogen peroxide in relation to mammalian cell proliferation. Free Radical Biology and Medicine 18 $775-794$.

Carroll JS, Liu XS, Brodsky AS, Li W, Meyer CA, Szary AJ, Eeckhoute J, Shao W, Hestermann EV, Geistlinger TR et al. 2005 Chromosomewide mapping of estrogen receptor binding reveals long-range regulation requiring the forkhead protein FoxA1. Cell 122 33-43.

Cheung PY, Churchich JE \& Lee KS 1999 Refolding of thioredoxin reductase assisted by groEL and PDI. Biochemical and Biophysical Research Communications 255 17-22.

Creekmore AL, Walt KA, Schultz-Norton JR, Ziegler YS, McLeod IX, Yates JR \& Nardulli AM 2008 The role of retinoblastoma associated proteins 46 and 48 in estrogen receptor alpha mediated gene expression. Molecular and Cellular Endocrinology 291 79-86.

Curtis CD, Likhite VS, McLeod IX, Yates JR \& Nardulli AM 2007 Interaction of the tumor metastasis suppressor nonmetastatic protein 23 homologue $\mathrm{H} 1$ and estrogen receptor alpha alters estrogenresponsive gene expression. Cancer Research 67 10600-10607.

Curtis CD, Thorngren DL, Ziegler YS, Sarkeshik A, Yates JR \& Nardulli AM 2009 Apurinic/apyrimidinic endonuclease 1 alters estrogen receptor activity and estrogen responsive gene expression. Molecular Endocrinology 23 1346-1359.

Das KC, Lewis-Molock Y \& White CW 1997 Elevation of manganese superoxide dismutase gene expression by thioredoxin. American Journal of Respiratory Cell and Molecular Biology 17 713-726.

Deroo BJ, Hewitt SC, Peddada SD \& Korach KS 2004 Estradiol regulates the thioredoxin antioxidant system in the mouse uterus. Endocrinology 145 5485-5492.

Druege PM, Klein-Hitpass L, Green S, Stack G, Chambon P \& Ryffel GU 1986 Introduction of estrogen-responsiveness into mammalian cell lines. Nucleic Acids Research 14 9329-9337.

Eckert RL \& Katzenellenbogen BS 1982 Effects of estrogens and antiestrogens on estrogen receptor dynamics and the induction of progesterone receptor in MCF-7 breast cancer cells. Cancer Research 42 139-144.

Feinendegen LE 2005 Evidence for beneficial low level radiation effects and radiation hormesis. British Journal of Radiology $\mathbf{7 8}$ 3-7.

Felty Q, Xiong WC, Sun D, Sarkar S, Singh KP, Parkash J \& Roy D 2005 Estrogen-induced mitochondrial reactive oxygen species as signaltransducing messengers. Biochemistry 44 6900-6909.

Finkel T \& Holbrook NJ 2000 Oxidants, oxidative stress and the biology of ageing. Nature 408 239-247.

Fujino G, Noguchi T, Takeda K \& Ichijo H 2006 Thioredoxin and protein kinases in redox signaling. Seminars in Cancer Biology 16 $427-435$

Goldstein BJ, Mahadev K, Wu X, Zhu L \& Motoshima H 2005 Role of insulin-induced reactive oxygen species in the insulin signaling pathway. Antioxidants $\mathcal{E}$ Redox Signaling 7 1021-1031.

Green S, Walter P, Kumar V, Krust A, Bornert J-M, Argos P \& Chambon P 1986 Human oestrogen receptor cDNA: sequence, expression and homology to v-erb-A. Nature 320 134-139.

Greene GL, Gilna P, Waterfield M, Baker A, Hort Y \& Shine J 1986 Sequence and expression of human estrogen receptor complementary DNA. Science 231 1150-1154.

Halliwell B \& Gutteridge JM 1985 The importance of free radicals and catalytic metal ions in human diseases. Molecular Aspects of Medicine 8 89-193.

Harman D 1956 Aging: a theory based on free radical and radiation chemistry. Journal of Gerontology 11 298-300.

Harman D 2001 Aging: overview. Annals of the New York Academy of Sciences 928 1-21.

Hashemy SI, Ungerstedt JS, Zahedi Avval F \& Holmgren A 2006 Motexafin gadolinium, a tumor-selective drug targeting thioredoxin reductase and ribonucleotide reductase. Journal of Biological Chemistry 281 10691-10697.
Hayashi S, Hajiro-Nakanishi K, Makino Y, Eguchi H, Yodoi J \& Tanaka H 1997 Functional modulation of estrogen receptor by redox state with reference to thioredoxin as a mediator. Nucleic Acids Research 25 4035-4040.

Hirota K, Matsui M, Iwata S, Nishiyama A, Mori K \& Yodoi J 1997 AP-1 transcriptional activity is regulated by a direct association between thioredoxin and Ref-1. PNAS 94 3633-3638.

Hirota K, Murata M, Sachi Y, Nakamura H, Takeuchi J, Mori K \& Yodoi J 1999 Distinct roles of thioredoxin in the cytoplasm and in the nucleus. A two-step mechanism of redox regulation of transcription factor NF-kappaB. Journal of Biological Chemistry 274 27891-27897.

Holmgren A 1979 Reduction of disulfides by thioredoxin. Exceptional reactivity of insulin and suggested functions of thioredoxin in mechanism of hormone action. Journal of Biological Chemistry 254 9113-9119.

Holmgren A 1985 Thioredoxin. Annual Review of Biochemistry 54 $237-271$.

Holmgren A \& Bjornstedt M 1995 Thioredoxin and thioredoxin reductase. Methods in Enzymology 252 199-208.

Jakupoglu C, Przemeck G, Schneider M, Moreno S, Mayr N, Hatzopoulos A, de Angelis M, Wurst W, Bornkamm G, Brielmeier M et al. 2005 Cytoplasmic thioredoxin reductase is essential for embryogenesis but dispensable for cardiac development. Molecular and Cellular Biology 25 1980-1988.

Jayaraman L, Murthy KG, Zhu C, Curran T, Xanthoudakis S \& Prives C 1997 Identification of redox/repair protein Ref-1 as a potent activator of p53. Genes and Development 11 558-570.

Katzenellenbogen BS, Kendra KL, Norman MJ \& Berthois Y 1987 Proliferation, hormonal responsiveness, and estrogen receptor content of MCF-7 human breast cancer cells grown in the short-term and long-term absence of estrogens. Cancer Research 47 4355-4360.

Kim J, Petz LN, Ziegler YS, Wood JR, Potthoff SJ \& Nardulli AM 2000 Regulation of the estrogen-responsive pS2 gene in MCF-7 human breast cancer cells. Journal of Steroid Biochemistry and Molecular Biology 74 157-168.

Kirkwood T \& Austad S 2000 Why do we age? Nature 408 233-238.

Lehnert BE \& Iyer R 2002 Exposure to low-level chemicals and ionizing radiation: reactive oxygen species and cellular pathways. Human $\mathcal{E}$ Experimental Toxicology 21 65-69.

Liang X, Lu B, Scott GK, Chang CH, Baldwin MA \& Benz CC 1998 Oxidant stress impaired DNA-binding of estrogen receptor from human breast cancer. Molecular and Cellular Endocrinology 146 151-161.

Lincoln DT, Ali Emadi EM, Tonissen KF \& Clarke FM 2003 The thioredoxin-thioredoxin reductase system: over-expression in human cancer. Anticancer Research 23 2425-2433.

Lundstrom J \& Holmgren A 1990 Protein disulfide-isomerase is a substrate for thioredoxin reductase and has thioredoxin-like activity. Journal of Biological Chemistry 265 9114-9120.

Lyles MM \& Gilbert HF 1991 Catalysis of the oxidative folding of ribonuclease A by protein disulfide isomerase: pre-steady-state kinetics and the utilization of the oxidizing equivalents of the isomerase. Biochemistry 30 619-625.

Makino Y, Okamoto K, Yoshikawa N, Aoshima M, Hirota K, Yodoi J, Umesono K, Makino I \& Tanaka H 1996 Thioredoxin: a redoxregulating cellular cofactor for glucocorticoid hormone action. Cross talk between endocrine control of stress response and cellular antioxidant defense system. Journal of Clinical Investigation $\mathbf{9 8}$ 2469-2477.

Maruyama T, Kitaoka Y, Sachi Y, Nakanoin K, Hirota K, Shiozawa T, Yoshimura Y, Fujii S \& Yodoi J 1997 Thioredoxin expression in the human endometrium during the menstrual cycle. Molecular Human Reproduction 3 989-993.

Maruyama T, Sachi Y, Furuke K, Kitaoka Y, Kanzaki H, Yoshimura Y \& Yodoi J 1999 Induction of thioredoxin, a redox-active protein, by ovarian steroid hormones during growth and differentiation of endometrial stromal cells in vitro. Endocrinology 140 365-372. 
Matsui M, Oshima M, Oshima H, Takaku K, Maruyama T, Yodoi J \& Taketo MM 1996 Early embryonic lethality caused by targeted disruption of the mouse thioredoxin gene. Developmental Biology 178 179-185.

Matthews JR, Wakasugi N, Virelizier JL, Yodoi J \& Hay RT 1992 Thioredoxin regulates the DNA binding activity of NF-kappa B by reduction of a disulphide bond involving cysteine 62. Nucleic Acids Research 20 3821-3830.

Mobley JA \& Brueggemeier RW 2004 Estrogen receptor-mediated regulation of oxidative stress and DNA damage in breast cancer. Carcinogenesis 25 3-9.

Mustacich D \& Powis G 2000 Thioredoxin reductase. Biochemical Journal 346 1-8.

Nardulli AM, Greene GL, O’Malley BW \& Katzenellenbogen BS 1988 Regulation of progesterone receptor messenger ribonucleic acid and protein levels in MCF-7 cells by estradiol: analysis of estrogen's effect on progesterone receptor synthesis and degradation. Endocrinology 122 935-944.

Nishi T, Shimizu N, Hiramoto M, Sato I, Yamaguchi Y, Hasegawa M, Aizawa S, Tanaka H, Kataoka K, Watanabe H et al. 2002 Spatial redox regulation of a critical cysteine residue of NF-kappa B in vivo. Journal of Biological Chemistry 277 44548-44556.

Noiva R, Freedman RB \& Lennarz WJ 1993 Peptide binding to protein disulfide isomerase occurs at a site distinct from the active sites. Journal of Biological Chemistry 268 19210-19217.

Nordberg J \& Arner ES 2001 Reactive oxygen species, antioxidants, and the mammalian thioredoxin system. Free Radical Biology and Medicine 31 1287-1312.

Osborne LJ, Tonissen KF, Tang VH \& Clarke FM 2001 Expression and localisation of thioredoxin in mouse reproductive tissues during the oestrous cycle. Molecular Reproduction and Development 58 359-367.

Powell C, Swenberg J \& Rusyn I 2005 Expression of base excision DNA repair genes as a biomarker of oxidative DNA damage. Cancer Letters 229 1-11.

Puig A, Lyles MM, Noiva R \& Gilbert HF 1994 The role of the thiol/disulfide centers and peptide binding site in the chaperone and anti-chaperone activities of protein disulfide isomerase. Journal of Biological Chemistry 269 19128-19135.

Quan H, Fan G \& Wang CC 1995 Independence of the chaperone activity of protein disulfide isomerase from its thioredoxin-like active site. Journal of Biological Chemistry 270 17078-17080.

Rao AK, Ziegler YS, McLeod IX, Yates JR \& Nardulli AM 2008 Effects of $\mathrm{Cu} / \mathrm{Zn}$ superoxide dismutase on estrogen responsiveness and oxidative stress in human breast cancer cells. Molecular Endocrinolgy 22 1113-1124.

Salganik RI 2001 The benefits and hazards of antioxidants: controlling apoptosis and other protective mechanisms in cancer patients and the human population. Journal of the American College of Nutrition 20 464S-472S (discussion 473S-475S).

Schultz-Norton JR, McDonald WH, Yates JR \& Nardulli AM 2006 Protein disulfide isomerase serves as a molecular chaperone to maintain estrogen receptor \{alpha\} structure and function. Molecular Endocrinology 20 1982-1995.

Schultz-Norton JR, Walt KA, Ziegler YS, McLeod IX, Yates JR, Raetzman LT \& Nardulli AM 2007 The deoxyribonucleic acid repair protein flap endonuclease-1 modulates estrogen-responsive gene expression. Molecular Endocrinology 21 1569-1580.

Schultz-Norton JR, Ziegler YS, Likhite VS, Yates JR \& Nardulli AM 2008 Isolation of novel coregulatory protein networks associated with DNA-bound estrogen receptor alpha. BMC Molecular Biology 997

Schultz-Norton JR, Ziegler YS, Likhite VS \& Nardulli AM 2009 Isolation of proteins associated with the DNA-bound estrogen receptor $\alpha$. In Molecular Endocrinology: A Comprehensive Guide to Current Methodologies, Eds O-K Park Sarge \& T Curry. Totowa, NJ, USA: Humana Press.
Smart DK, Ortiz KL, Mattson D, Bradbury CM, Bisht KS, Sieck LK, Brechbiel MW \& Gius D 2004 Thioredoxin reductase as a potential molecular target for anticancer agents that induce oxidative stress. Cancer Research 64 6716-6724.

Storz G, Tartaglia LA, Farr SB \& Ames BN 1990 Bacterial defenses against oxidative stress. Trends in Genetics 6 363-368.

Stossi F, Likhite VS, Katzenellenbogen JA \& Katzenellenbogen BS 2006 Estrogen-occupied estrogen receptor represses cyclin G2 gene expression and recruits a repressor complex at the cyclin G2 promoter. Journal of Biological Chemistry 281 16272-16278.

Sun QA, Wu Y, Zappacosta F, Jeang KT, Lee BJ, Hatfield DL \& Gladyshev VN 1999 Redox regulation of cell signaling by selenocysteine in mammalian thioredoxin reductases. Journal of Biological Chemistry 274 24522-24530.

Tam NN, Gao Y, Leung YK \& Ho SM 2003 Androgenic regulation of oxidative stress in the rat prostate: involvement of $\mathrm{NAD}(\mathrm{P}) \mathrm{H}$ oxidases and antioxidant defense machinery during prostatic involution and regrowth. American Journal of Pathology 163 2513-2522.

Toussaint O, Royer V, Salmon M \& Remacle J 2002 Stress-induced premature senescence and tissue ageing. Biochemical Pharmacology 64 1007-1009.

Turano C, Coppari S, Altieri F \& Ferraro A 2002 Proteins of the PDI family: unpredicted non-ER locations and functions. Journal of Cellular Physiology 193 154-163.

Turunen N, Karihtala P, Mantyniemi A, Sormunen R, Holmgren A, Kinnula VL \& Soini Y 2004 Thioredoxin is associated with proliferation, p53 expression and negative estrogen and progesterone receptor status in breast carcinoma. Acta Pathologica et Microbiologica Scandinavica 112 123-132.

Ueno M, Masutani H, Arai RJ, Yamauchi A, Hirota K, Sakai T, Inamoto T, Yamaoka Y, Yodoi J \& Nikaido T 1999 Thioredoxindependent redox regulation of p53-mediated p21 activation. Journal of Biological Chemistry 274 35809-35815.

Urig S \& Becker K 2006 On the potential of thioredoxin reductase inhibitors for cancer therapy. Seminars in Cancer Biology 16 452-465.

Wang CC \& Tsou CL 1993 Protein disulfide isomerase is both an enzyme and a chaperone. FASEB Journal 7 1515-1517.

Webster KA, Prentice H \& Bishopric NH 2001 Oxidation of zinc finger transcription factors: physiological consequences. Antioxidants and Redox Signaling 3 535-548.

Wei SJ, Botero A, Hirota K, Bradbury CM, Markovina S, Laszlo A, Spitz DR, Goswami PC, Yodoi J \& Gius D 2000 Thioredoxin nuclear translocation and interaction with redox factor-1 activates the activator protein-1 transcription factor in response to ionizing radiation. Cancer Research 60 6688-6695.

Westley BR \& May FE 1987 Oestrogen regulates cathepsin D mRNA levels in oestrogen responsive human breast cancer cells. Nucleic Acids Research 15 3773-3786.

Wood JR, Likhite VS, Loven MA \& Nardulli AM 2001 Allosteric modulation of estrogen receptor conformation by different estrogen response elements. Molecular Endocrinology 15 1114-1126.

Wu X, Bishopric NH, Discher DJ, Murphy BJ \& Webster KA 1996 Physical and functional sensitivity of zinc finger transcription factors to redox change. Molecular and Cellular Biology 16 1035-1046.

Xanthoudakis S \& Curran T 1992 Identification and characterization of Ref-1, a nuclear protein that facilitates AP-1 DNA-binding activity. EMBO Journal 11 653-665.

Yoshida T, Oka S, Masutani H, Nakamura H \& Yodoi J 2003 The role of thioredoxin in the aging process: involvement of oxidative stress. Antioxidants and Redox Signaling 5 563-570.

Received in final form 1 July 2009

Accepted 20 July 2009

Made available online as an Accepted Preprint 20 July 2009 